Neth. J. Agric. Sci., 16 (1968) : 204-210

\title{
Two model experiments on the durability of subsoil compaction
}

C. van Ouwerkerk

Institute for Soil Fertility, Haren-Groningen, The Netherlands

Received 31 May, 1968

\begin{abstract}
Summary
To study possible changes in pore space and air content of a compacted subsoil layer, two model experiments were conducted on a sandy loam. In the first experiment no crop was grown, while in the second one the effects of plant growth and farmyard manure were investigated.

The first experiment showed that on fallow land a compaction in the subsoil neither disappeared nor changed substantially in the course of $31 / 2$ years.

From the second experiment it is concluded that even in a soil where a crop is grown and soil fauna is stimulated by shallow application of farmyard manure, a compaction in the subsoil will not disappear rapidly. After $61 / 2$ years distinct changes in pore space or air content still could not be found. A positive effect of plant growth and of farmyard manure was only observed in the topsoil.
\end{abstract}

\section{Introduction}

Moving heavy agricultural machinery across agricultural soils confronts us with the problem of soil compaction. The compacting influence of the pressure exerted is often perceptible to a depth below that of normal soil-tillage practices (Kuipers, 1963). Therefore, under the ploughed layer densities higher than normal may occur, which sometimes hamper plant growth. The density may be so high that root penetration is impossible (Van Ouwerkerk, 1965). Under certain conditions the dense subsoil may cause stagnation of water, which reduces the air supply of the roots and may lead to slaking of the topsoil (Altemüller, 1959).

According to Görbing (Domsch, 1959) the soil fauna plays an important part in the ploughed layer only. At a greater depth climatic influences are generally not important, so no 'Selbstlockerung' (Bernard, 1964) is to be expected here. This means that without mechanical loosening (subsoiling) a compaction in the subsoil will not disappear at all, or only very slowly (under the influence of plant roots).

To verify this hypothesis $H$. Kuipers ${ }^{1}$ initiated a model experiment in the field, which was followed by a second one carried out by the present author.

\section{Procedure}

The first experiment was started in December, 1957, on a sandy loam, susceptible to slaking (Table 1). To eliminate the influence of plant roots no crop was grown while weeds were removed by shallow hoeing.

1 Since 1960: Laboratory of Soil Tillage, Agricultural University, Wageningen, The Netherlands. 
TWO MODEL EXPERIMENTS ON THE DURABILITY OF SUBSOIL COMPACTION

Table 1 Soil characteristics

\begin{tabular}{rccccc}
\hline $\begin{array}{c}\text { Depth } \\
(\mathrm{cm})\end{array}$ & $\mathrm{pH}-\mathrm{KCl}$ & \multicolumn{4}{c}{ Percentage of oven-dry weight } \\
\cline { 3 - 6 } & & $\mathrm{CaCO}$ & $\begin{array}{c}\text { organic } \\
\text { matter }\end{array}$ & $\begin{array}{c}\text { 'silt' } \\
(<16 \mu)\end{array}$ & $(<2 \mu)$ \\
& & & & & clay \\
$0-10$ & 7.5 & 2.5 & 2.2 & 20.3 & 12.8 \\
$10-20$ & 7.5 & 2.4 & 1.2 & 24.8 & 16.0 \\
$20-30$ & 7.3 & 2.6 & 0.9 & 25.2 & 16.2 \\
$30-40$ & 7.2 & 2.4 & 1.0 & 24.3 & 15.6 \\
\hline
\end{tabular}

On all plots the topsoil was removed. The subsoil $(18-38 \mathrm{~cm})$ remained in its original state on plot $\mathrm{A}$, but on plots $\mathrm{B}$ and $\mathrm{C}$ it was removed. On plot $\mathrm{B}$ the subsoil was replaced without compaction while on plot $C$ it was very heavily compacted by replacing the soil in shallow layers under continuous tamping (dynamic load not determined). Then the topsoil was replaced without compaction on all plots. Plot size was $1.5 \times 2 \mathrm{~m}^{2}$; there were no replicates.

At intervals pore space, moisture, and air content were determined. After $31 / 2$ years too little undisturbed soil was left to enable sampling. Consequently, this experiment was terminated.

The second experiment was started on the same soil in March, 1962. Subsoil treatments $(18-40 \mathrm{~cm})$ were: loosened, lightly compacted $\left(1 / 2 \mathrm{~kg} / \mathrm{cm}^{2}\right)$ and heavily compacted $\left(1 \mathrm{~kg} / \mathrm{cm}^{2}\right)$. On all plots the previously removed topsoil was replaced without compaction.

In this experiment spring barley, flax, oats, peas, spring wheat, and sugar-beets were grown successively. On one half of each plot plant growth and soil fauna were stimulated by shallow application of farmyard manure $(40 \mathrm{t} / \mathrm{ha})$ in years in which the crop permitted this. Soil cultivation was restricted to hoeing, raking, and very shallow digging $(7 \mathrm{~cm})$. Plot size was $6 \times 2 \mathrm{~m}^{2}$; there were no replicates. Due to circumstances this experiment had to be terminated by the end of 1967 .

\section{Results}

Fallow land

Pore space fluctuated rather strongly, especially in the first part of the experiment. The fluctuations decreased with depth (Fig. 1). Seasonal soil-structure variations are well-known (Rid, 1961). In this case, however, irregular soil settlement could also be a reasonable explanation.

In the $2-7 \mathrm{~cm}$ layer only small differences existed between treatments. The initially high pore space gradually decreased so that on plots $A$ and $B$ the difference with the subsoil disappeared gradually. On the very heavily compacted plot $\mathrm{C}$ the initial difference in pore space between topsoil and subsoil was so large, that after $3 \frac{1}{2}$ years it was still significant.

In the 7-12 cm layer plots $A$ and $B$ had about the same pore space, especially in the later years of the experiment. On plot $C$ pore space was systematically lower which suggests an originally higher rate of settlement, possibly caused by stagnation of water on the denser subsoil.

In the 7-12 cm layer pore space decreased at about the same rate as in the $2-7 \mathrm{~cm}$ 

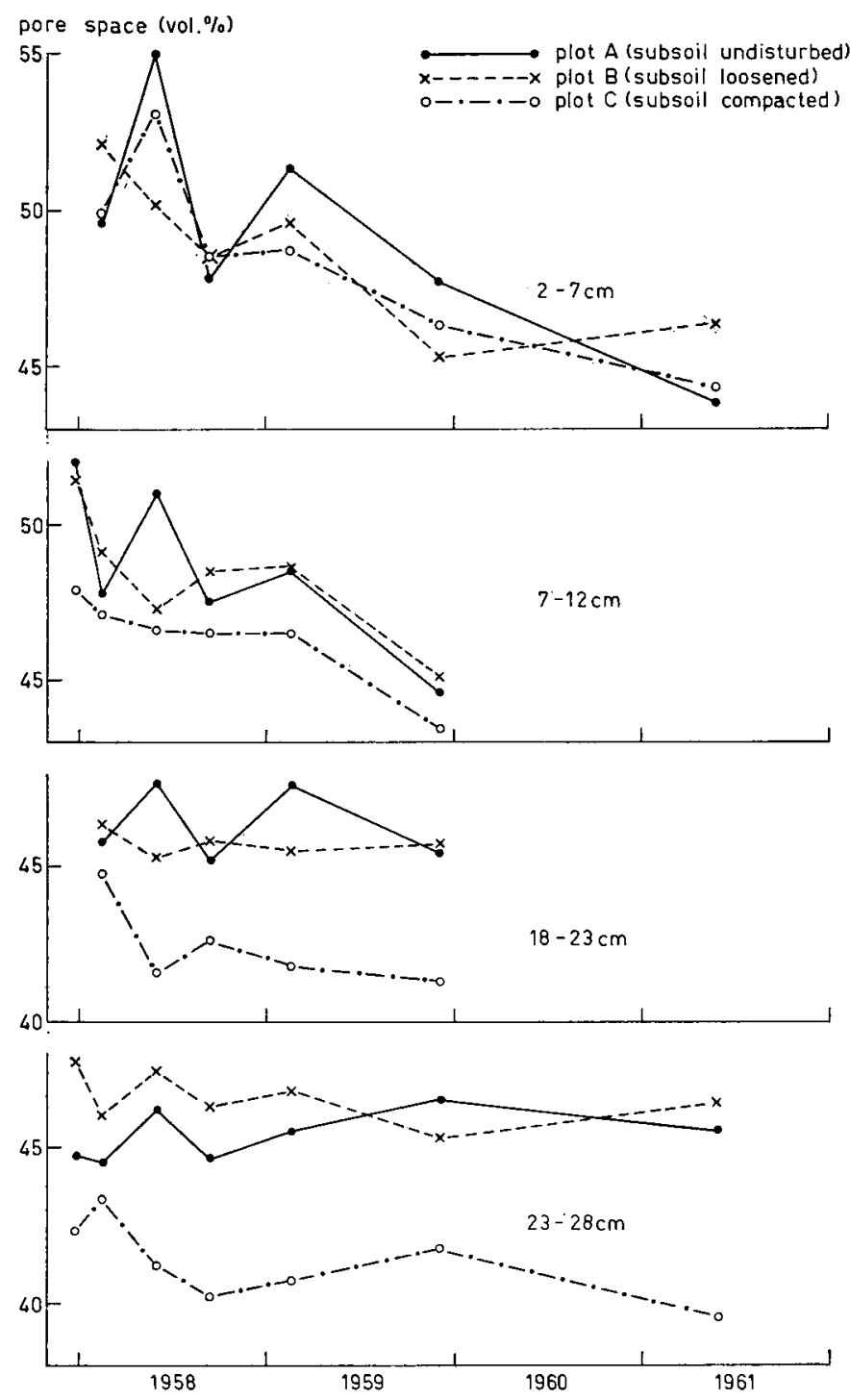

Fig. 1 Pore-space changes in the course of time (fallow land)

layer. Apparently, the settlement of loosened topsoil proceeds for years until a terminal value is reached equal to that of the natural subsoil (here about 45 vol. \%). In the 18-23 cm layer treatment B (loosened) was found not to have a lower density than treatment $A$ (undisturbed). The difference with treatment $C$ (very heavily compacted) was somewhat bigger than in the 7-12 cm layer. Apart from some fluctuations pore space did not change in this layer in the course of time. 


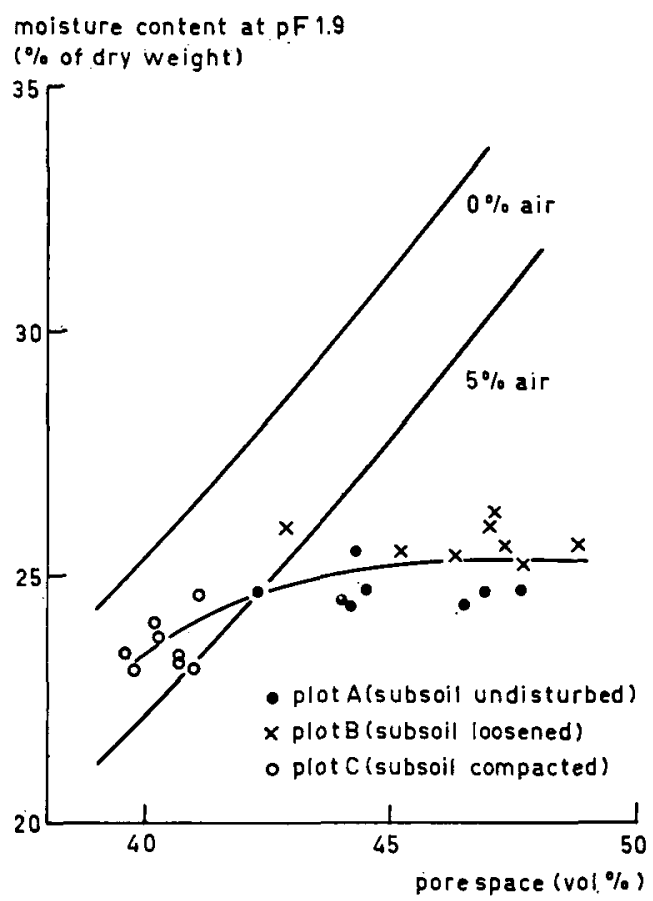

Fig. 2 Relationship between pore space and moisture content at $p F 1.9$ in the $23-28 \mathrm{~cm}$ layer (fallow land)

In the $23-28 \mathrm{~cm}$ layer (i.e. the middle of the compacted layer) pore space changed no more than in the $18-23 \mathrm{~cm}$ layer. Pore space on plot B seemed to be somewhat higher than on plot A. However, the differences were only small and decreased even more with time. On the very heavily compacted plot $\mathrm{C}$ pore space did stay about 4 vol.\% lower.

In the topsoil moisture content at $\mathrm{pF} 1.9$ was independent of pore space, which indicates a sufficient air content (Kuipers, 1961). In the 18-23 cm layer and particularly in the $23-28 \mathrm{~cm}$ layer the open circles, referring to the very heavily compacted plot C, caused the curve to turn off (Fig. 2). This phenomenon shows that under wet conditions ( $\mathrm{pF}$ 1.9) lack of air may be found in the subsoil of plot $\mathrm{C}$.

\section{Cropped land}

Pore space showed the usual fluctuations (Fig. 3). In contrast with the first experiment it increased steadily in the $7-12 \mathrm{~cm}$ layer, which could be understood as an effect of biological activity. This view is supported by the stronger increase of pore space on plots with farmyard manure.

In the subsoil systematic changes of pore space did not occur. Light compaction $\left(1 / 2 \mathrm{~kg} / \mathrm{cm}^{2}\right)$ of the $18-40 \mathrm{~cm}$ layer had about the same effect as had loosening, while heavy compaction $\left(1 \mathrm{~kg} / \mathrm{cm}^{2}\right)$ decreased pore space with only 2 vol.\%. Apparently, compaction was less severe than in the first experiment where it was called 'very heavy'.

In the subsoil the effect of shallow application of farmyard manure on pore space was positive, though small (Table 2): in the $22-27 \mathrm{~cm}$ layer pore space was about 
C. VAN OUWERKERK
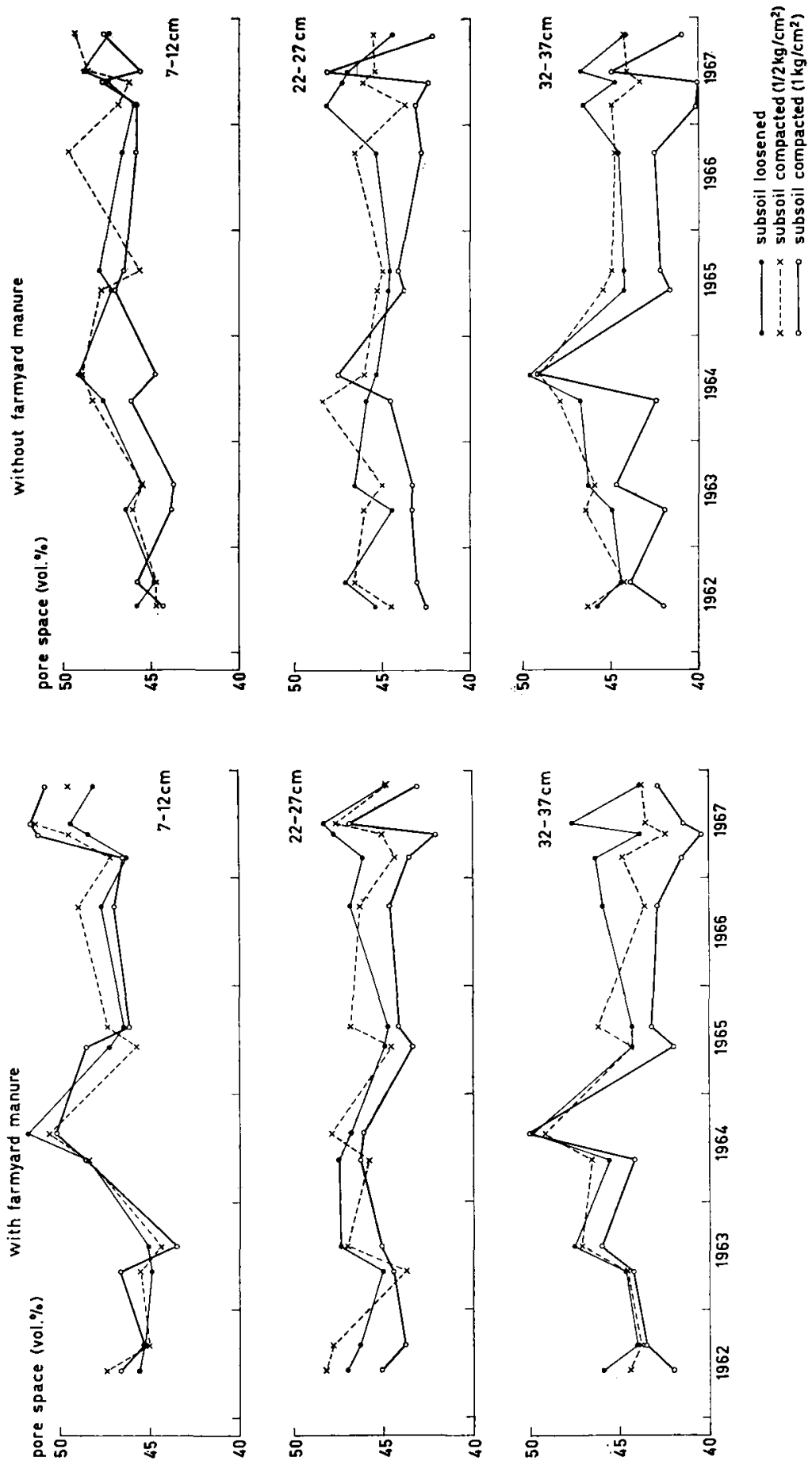

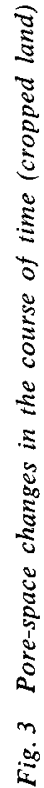


TWO MODEL EXPERIMENTS ON THE DURABILITY OF SUBSOIL COMPACTION

Table 2 Pore space, moisture, and air content at pF 2.0 (means for 1962 to 1967 inclusive). Farm yard manure shallow applicated

\begin{tabular}{|c|c|c|c|c|c|c|c|c|c|}
\hline & \multirow{2}{*}{$\begin{array}{c}\text { Depth } \\
(\mathrm{cm})\end{array}$} & \multicolumn{4}{|c|}{ Subsoil (with farmyard manure) } & \multicolumn{4}{|c|}{ Subsoil (without farmyard manure) } \\
\hline & & loosened & $\begin{array}{c}\text { lightly } \\
\text { compacted }\end{array}$ & $\begin{array}{c}\text { heavily } \\
\text { compacted }\end{array}$ & mean & loosened & $\begin{array}{c}\text { lightly } \\
\text { compacted }\end{array}$ & $\begin{array}{c}\text { heavily } \\
\text { compacted }\end{array}$ & mean \\
\hline $\begin{array}{l}\text { Pore space } \\
\text { (vol. \%) }\end{array}$ & $\begin{array}{r}7-12 \\
22-27 \\
32-37\end{array}$ & $\begin{array}{l}47.2 \\
46.4 \\
45.6\end{array}$ & $\begin{array}{l}47.7 \\
46.1 \\
44.9\end{array}$ & $\begin{array}{l}47.8 \\
44.5 \\
43.3\end{array}$ & $\begin{array}{l}47.6 \\
45.7 \\
44.6\end{array}$ & $\begin{array}{l}47.0 \\
45.8 \\
45.6\end{array}$ & $\begin{array}{l}47.1 \\
45.6 \\
45.5\end{array}$ & $\begin{array}{l}45.7 \\
43.8 \\
42.8\end{array}$ & $\begin{array}{l}46.6 \\
45.1 \\
44.6\end{array}$ \\
\hline $\begin{array}{l}\text { Air content } \\
\text { at } \mathrm{pF} 2.0 \\
\text { (vol. } \% \text { ) }\end{array}$ & $\begin{array}{r}7-12 \\
22-27 \\
32-37\end{array}$ & $\begin{array}{l}15.7 \\
14.5 \\
12.3\end{array}$ & $\begin{array}{l}15.8 \\
15.0 \\
12.3\end{array}$ & $\begin{array}{l}16.2 \\
12.0 \\
10.0\end{array}$ & $\begin{array}{l}15.9 \\
13.8 \\
11.5\end{array}$ & $\begin{array}{l}16.2 \\
13.6 \\
12.4\end{array}$ & $\begin{array}{l}16.1 \\
14.4 \\
13.5\end{array}$ & $\begin{array}{r}13.7 \\
11.2 \\
9.2\end{array}$ & $\begin{array}{l}15.3 \\
13.1 \\
11.7\end{array}$ \\
\hline
\end{tabular}

$1 / 2$ vol. \% higher on the plots with farmyard manure, while in the $32-37 \mathrm{~cm}$ layer the lowest pore space was found on the heavily compacted plot without farmyard manure.

Moisture content at $\mathrm{pF} 2.0$ fluctuated not much. On an average it was equal for both lightly and heavily compacted plots (Table 2). On the loosened plot it remained $1 / 2$ to $1 \%$ higher in the subsoil. The effect of farmyard manure was negligible.

On the loosened plot air content was somewhat lower than on the compacted plots, due to the somewhat higher moisture content (Table 2). The lowest air content was found on the heavily compacted plot. Because of its favourable effect on pore space, farmyard manure had a positive, though very small effect on air content at $\mathrm{pF} 2.0$. From vigour marks and yield data the effect of light compaction on plant growth was found to be negligible. Heavy compaction, however, sometimes had an adverse effect. Farmyard manure stimulated plant growth and diminished the adverse effect of heavy compaction.

\section{Conclusions}

In the first experiment (fallow land) the effect of loosening the subsoil on pore space was negligible. Very heavy compaction, however, decreased pore space with about 4 vol.\%, causing lack of air under wet conditions. This compaction did neither disappear nor change substantially in the course of $31 / 2$ years. Loosening the topsoil increased pore space considerably but only temporarily. Initially it decreased fairly rapidly, thereafter much more slowly till the density of the natural subsoil was reached.

In the second experiment (cropped land) light compaction $\left(1 / 2 \mathrm{~kg} / \mathrm{cm}^{2}\right)$ had about the same effect on pore space as had loosening. Loosened subsoil did not settle consistently. Heavy compaction $\left(1 \mathrm{~kg} / \mathrm{cm}^{2}\right)$ decreased pore space with about 2 vol.\% and air content with about $2 \frac{1}{2}$ vol. $\%$. In spite of vigourous plant growth even this relatively small subsoil compaction was found to be unchanged after $61 / 2$ years. 


\section{VAN OUWERKERK}

\section{References}

Altemüller, H. J., 1959. Untersuchungen über die Aggregatstabilität verschiedener Bodentypen auf Löss. Mededel. Landbouwhogeschool Opzoekingssta. Staat Gent, 24 : 58-63.

Bernard, H., 1964. Untersuchungen an Pflugsohlenverdichtungen mit verschiedenen Methoden. Thesis, Friedrich-Wilhelms-Univ., Bonn, $102 \mathrm{pp}$.

Domsch, M., 1959. Probleme der Bodenbearbeitung. 2. Auflage. VEB Deutscher Landwirtschaftsverlag, Berlin, $164 \mathrm{pp}$.

Kuipers, H., 1961. Water content at $\mathrm{pF} 2$ as a characteristic in soil-cultivation research in the Netherlands. Neth. J. Agr. Sci., $9: 27-35$.

Kuipers, H., 1963. Drukverdeling onder landbouwvoertuigen. Landbouwmechanisatie, 14 : 1-8.

Ouwerkerk, C. van, 1965. Invloed van de ploegdiepte op de chemische en fysische eigenschappen van een hoge esgrond. Landbouwk. Tijdschr., $77:$ 850-859.

Rid, H., 1961. Strukturveränderungen des Ackerbodens im Bereich der Krume, der Pflugsohle und des Untergrundes, nachgewiesen durch Strukturdiagnosen und Messungen der Grobstruktur. $Z$. Acker Pflanzenbau, 114 : 58-86. 